The basis of good manners is self-reliance.

Ralph Waldo Emerson

\title{
Youth, creativity and urban life: insights from classics
}

\section{Frederick Kang'ethe Iraki}

\begin{abstract}
Youth and leadership appear to be antinomical concepts in modern Kenya. Similarly, youth on one side, and creativity and entrepreneurship on the other appear to be strange bed-fellows. The youth are quasisynonymous with want of leadership, intellectual dullness, indolence, over-reliance on parents and teachers, and lack of enterprise. This phenomenon stands in stark contrast with traditional African ethos and social mores.

In traditional African setting, the role of the youth was well defined and demarcated. The youth represented that tranche of age between childhood and adulthood. It symbolized the preparation to assume family and community responsibility. Invariably, it was heralded by a rite of passage. Subsequently, the youth were initiated into various chores and codes of behavior to prime them to take over leadership roles. These included warriors, raiders, elders to adjudicate over disputes, etc. ${ }^{1}$

With the advent of urbanization, traditional African life mutates rapidly as the pressure of modern life redefines social roles and responsibilities. The youth is faced with a conflict of cultures, urban poverty, parental neglect, and lack of a social compass to direct their lives. In response to these iniquities, the youth devise strategies, linguistic or otherwise, to cope with this seemingly indifferent and oppressive urban context.

This paper attempts to discuss the condition of the youth in Nairobi with a view to documenting the challenges they face and strategies that could help them cope (or overcome) some of the daunting hardships put in their way by the imperatives of a fast uncoordinated mutations of the City. The paper draws inspiration from outstanding authors who have successfully tackled the issue of personal economic prosperity and self-reliance. Success begins with the individual, not society.
\end{abstract}

Key words: self-reliance, prosperity, success, youth, entrepreneurship, urban

\footnotetext{
${ }^{1}$ For a review of traditional societal life see The Agikuyu (Cagnolo et al. 1938/1994), Facing Mount Kenya (Kenyatta 1934), Roots (Haley 1991), Rites et croyances des peuples du Gabon (Raponda-Walker \& Roger sillans (2005).
} 


\section{Introduction}

The youth encompasses the tranche of age between childhood and adulthood; say the 13-23 years fork. The ten-year period includes tremendous biological, emotional, psychological, physical and social mutations in the life of a young person. As the hormones gush through the endocrine system, the youth change, not only in appearance but also in the manner they interact with their social environment. They become anxious about their relationships with each other, especially the opposite sex, as they grapple with new social realities.

The same period is compounded by at least three national gate-keeping examinations: the end of primary examinations (Kenya Certificate of Primary Education) at age 13, the Kenya Secondary Certificate of Education at about 17 years, and the first degree at university at about age 21-22. During this period the youth enjoy more stewardship and guidance from the house-helps, school teachers (or lecturers) and minimally from the clergy. Parents, caught up in the rat-race of the urban life, arguably spend less time with their brood.

The economic and social realities of the City life rob the youth of invaluable parental guidance and scaffolding, laying them bare to a host of depredations and vulgarities. Those who cannot withstand the pressure take to the streets in search of a better life. They can no longer trust society to nurture them into productive people. Society seems to have conspired to eliminate them from the face of the earth. As St. Augustine once said Trust not the world, for it never payeth what it promises. However, these youth have aspirations and dreams to succeed in life just like those who remain in the fragile families (See Martin Njoroge's article on Street-children in Nairobi ${ }^{2}$ ).

Politically, the youth play the critical role of voting in the political class in Kenya. By the end of the high school cycle, the youth have attained the suffrage age of 18 years and therefore can participate in national as well as local elections. The politicians prey on this vulnerable age-group, coaxing them with enticements and empty rhetoric. Without parental direction, the youth succumb easily as they have no alternative paradigm of values to shine the way for them.

On the other hand, women have somewhat managed to navigate the treacherous waters of phallocratic politics. In recent times, they have managed to wrestle important political positions from the men. $A$ contrario, the youth have had little if any gains to make from the political game. The Kenya Government, irrespective of the political dispensation, has created various youth ministries with little more than political gimmickry. The youth have remained politically marginalized after the election poll. Beyond the ballot box, the youth have been largely irrelevant politically.

In the realm of economics, the Kenyan youth has been disempowered since they cannot, like their counterparts in Western Europe or USA, find part-time jobs in restaurants, bars, shops, etc. These job opportunities have been taken up by older persons desperate for survival in the City. This means the youth have to bide their time until they terminate university studies, i.e. waiting for more than 10 years to be economically active!

\footnotetext{
2 “Education as a tool for empowering Kenya's street children for integration in national development In Journal of Language, Technology \& Entrepreneurship in Africa, 2009.
} 
The picture is rendered all the more bleak by the educational system in Kenya whose values are in contradiction with the modern needs of the country. For instance, the youth are educated so that they can "find work" in the job market. This naïve view of the Kenyan economy makes it hard for the youth to develop an entrepreneurial spirit that would eventually lead to self-reliance, self-employment, etc. Most of our university graduates do not expect to create anything in their lives. Rather, they expect someone to take care of them, absorb them into work and give them a means of sustenance and succor.

The first part of this discussion will deal with historical transformations in Kenya that preface the life of the youth in the City. It will delve into historical and political factors that have contributed to the current quagmire for the youth.

The second part will discuss issues of creativity and innovation and how the youth have displayed these attributes.

The final part brings to bear insights from classic and modern authors on how to circumnavigate the challenges of life in order to lead a successful life. At the risk of being too prescriptive, the section outlines the main traits of a successful economic life.

\section{Growing up in the City of Nairobi}

Mutongi (2006) recounts the socio-economic mutations of western Kenya with the advent of an urban culture thanks to the discovery of gold mines by colonialists at Ikolomani ${ }^{3}$. The placid traditional African life had been disrupted considerably by the European colonialist whose devastating arrival in the region had been presaged by the Missionaries, notably the Quakers.

The mines required paid labor from the African men who in turn required leaving their traditional huts to huddle in cramped hovels in the new town life. Prostitution quickly set in since the men now had to compensate the mistresses they had acquired in the town. Efforts to repudiate the women by the colonial administration were fruitless as the demand for their services were incredibly high.

The poor salaries, coupled with the need to maintain two "homes" -one in town and another in the rural setting - seriously eroded the quality of life for most homesteads. Further, the poor living conditions in the town were not any dissimilar to those in medieval to $18^{\text {th }}$ Century France ${ }^{4}$.

In this new urban environment, the youth were to find themselves largely abandoned by working class parents, torn between the increasing working hours and meager remuneration.

The genesis of the kakamega town may be different from that of the City of Nairobi ${ }^{5}$. Maina wa Kinyatti (2007) indicates that the Kenya-Uganda Railway imperialists selected the spot to build their headquarters in the late $19^{\text {th }}$ Century. The town that ensued was to have more sophistication as it became the capital of the colony after 1920 .

\footnotetext{
${ }^{3}$ The term ikolomani is a derived from goldmine.

${ }^{4}$ The French lived in squalid quatters in towns infested with rodents and with poor drainage before the $19^{\text {th }}$ Century (Roger 2003????).

${ }^{5}$ The term means a place of cool water in the Maasai language.
} 
Like most primeval towns, Nairobi was to resemble Kakamega in many respects: Poor sanitations, poor living quarters, cultural dislocation, unequal opportunities, disease, and economic disempowerment for the majority of the people. Little wonder then that at the advent of Independence in 1963, the Kenyatta Government promised to focus on eradicating poverty, disease and ignorance.

As many people from all ethnic communities flocked into the City in search of a better life, the living conditions moved from bad o worse. New slums mushroomed and older ones burgeoned to become gigantic living nightmares like Kibera, Kawangware, Kariobangi, etc.

In this context, the youth were to contend with a number of problems. Firstly, they spent more time at school than at home, leaving the teachers to be in charge of guiding them. At home, pressure was mounting for the jobless or poorly-paid parents to share their time between the kids and the workplace. For the slightly well-off, the house-helps filled the gap. It is important to note that the house-helps were in the main unschooled.

Secondly, the youth -unlike their rural counterparts who engaged in agricultural activities -had to create new ways of socializing. Gangs were formed to socialize as well as fight for supremacy in the neighborhoods. Survival depended on a witty choice of the group that can secure one's safety. Gang fights between the youth were quite frequent, especially in Bahati, Jericho, Maringo, Kaloleni, Makongeni and Makadara. ${ }^{6}$

Thirdly, the confluence of so many ethnic languages, Kiswahili and English (at school) offered the youth a rainbow of linguistic options from which they could craft their own idiom that would be bereft of ethnic labeling. This appears to be the genesis of the sheng language.

Fourthly, the economic disempowerment meant little in terms of providing for sporting opportunities. The youth improvised greatly to create "soccer balls" from a mixture of papers and polythene wraps. The other games requiring little or minimum equipment included boxing, karate and athletics.

In sum, the situation in the City was little different from the scenes described in Charles Dickens's Hard times and John Steinbeck's Grapes of Wrath. Hardship and survival characterize the life of the youth in the city. But how do the youth cope with the miasma of urban challenges?

\section{Youth and creativity}

The youth have a repertoire of strategies to navigate the murky waters of the City. These include resilience, copy-cat behavior, creativity and enterprise.

\subsection{Resilience}

In the absence of clear-cut social beacons to regulate their lives, the youth invariably resort to religion. Religion, whether a con or not, seems to responds to the queries of the heart. The incomprehensible, the impalpable and the unthinkable all assume some form of meaning for the human mind, especially the

\footnotetext{
${ }^{6}$ These neighborhoods in the Eastern part of the City. Traditionally, they are more economically-challenged than the loftier Westlands neighborhoods.
} 
vulnerable mind. ${ }^{7}$ The youth find an anchor in religion to hold everything together and help them make sense of their world.

In Nairobi, the Mungiki group begun as a religious group rekindling old Gikuyu form of worship and rejecting the modern religions. The latter were associated with the economic disempowerment of the youth and the country. The new religion offered hope and redemption for the Gikuyu youth. The group metamorphosed into a terror gang along the sides of the Italian Mafia. The gang's existence and proliferation may be explained by the socio-economic malaise that has bedeviled Kenya for about four and a half decades.

The Charismatic churches mushroomed between the 1980s and 2000s. These outfits target the youth and the middle-classes for their economic success. The youth crowd in them as a haven to help them find meaning in their existence. Religion is seen as the panacea to all the ills of society. We hasten to mention that given the dearth of social values in the City and the absence of parental mentorship, the youth stand to gain from the values inculcated by the Church, the Mosque or the Temple.

In the worst case scenario, religion becomes the Opium of the people as Karl Max opined. It exploits and dulls the human spirit to maintain man in bondage. The youth, being fragile, are beguiled to spent their meager resources and time on religious matters.

The youth who have no religious teaching have to rely on its own intellectual resources to make sense of life. Arguably, this is a tougher route since the youth has to mobilize colossal resources to construct its own paradigm of social mores and ethos. In both scenarios, religious and non-religious, the youth manage to cope with a meaningless world.

\subsection{Echo behavior}

The youth in urban centers are better exposed to trends in the developed world, especially from the USA. In the 1960/70ss, the mini-skirt, the ripples of Black Power movement, the Afro hair and belly-bottom trousers were cultural phenomena that influenced the youth of the time.

The emergence of the Hip-Hop style of music in Kenya echoes a similar trend in the 1970s in the USA (Kimani Njogu 2006????). The harsh socio-economic conditions of Blacks in the US in the 1970s resemble the challenges of the Youth in Kenya today; hence, the resurgence of the hip-hop style. The music recounts social and economic hardships that the Youth face every day.

\subsection{Creativity}

Creativity or innovation is one of the astonishing feats of the Kenyan youth. The youth create artifacts for sports (balls, hoops, car tyres, etc) in early childhood years. However, this creativity seems to wax and wane as the youth enter adolescence. ${ }^{8}$ At this point in time, the school system is more concerned with success in traditional subjects (sciences and humanities). There is little if any room left for innovation.

\footnotetext{
${ }^{7}$ See Dawkins' God delusion and Ayn Rand's Atlas Shrugged for a different view of religion.

${ }^{8}$ Observation by Prof. Karega-Munene during an informal chat with author.
} 
Despite this school constraint, the youth manage to innovate in several areas that we now turn to.

\subsubsection{Sheng Language}

Studies of Sheng show incontrovertible evidence that sheng is a language that was created by the youth to serve various purposes (Ireri-Mbaabu 1996, Abdulazziz \& Osinde 2001, Githiora 2003 and Iraki 2004). The language serves to include and also to exclude. But away from this functionality, the language whose syntax is roughly derived from standard Kiswahili presents an array of picturesque words (mainly nouns and verbs) to convey meaning.

The lexicon sloughs off every 5 years or so, and a new arsenal is created (cf. Table 1) ${ }^{9}$. This linguistic versatility attests to the great creative potential of the youth. As the school system attempts to force the mastery of English and Kiswahili, and as parents insist on ethnic languages, the youth continue to re-arm and rejuvenate an idiom that they feel is devoid of ethnic nationalism and school pressure. Sheng.

\begin{tabular}{|l|l|l|l|l|}
\hline Item/sheng & $\mathbf{1 9 7 0}$ & $\mathbf{1 9 8 0}$ & $\mathbf{1 9 9 0}$ & $\mathbf{2 0 0 0}$ \\
\hline Money, dough & Maniado, doo & Doo, arija & Chapaa, kwacha & Munde \\
\hline To eat & kuminya & kusosi & kudishi & kumanga \\
\hline 500 shillings note & - & - & jirongo & Soo tano \\
\hline 1000 shillings & - & - & Patni, ngiri & Muti, ngiri \\
\hline To have sex & Kudinya, kuthona & kuduu & kufagia & kubinja \\
\hline policeman & Sonyi, ponyi & koopa & mahindra & karao \\
\hline guy & mjamaa & chali & msee & msee \\
\hline chick & deemu & Manzi, chik & manzi & manzi \\
\hline
\end{tabular}

Table 1: Some examples of Sheng's evolution

The use of sheng by politicians during the last two General Elections in Kenya give credence to the increasing importance of the idiom. Further, the employ of Sheng in major advertizing outlets including the two major mobile phone services providers, Safaricom and Zain underscore the economic importance of the language. If the youth account for about $60 \%$ of the Kenyan population, then it makes sense to engage them in their own language. Sheng.

In the domain of performing arts, Sheng has made great strides in the local acting theatres and on the music scene. Plays in Sheng are now more common and acceptable than before the 1990s. In music, the youth have been singing in Sheng much to the delight of their fans who now can "connect" with the issues at hand.

\subsubsection{Music}

The youth have been incredibly active since the 1990s in the arenas of benga, hip-hop and gospel music. As compared to previous periods there has been a plethora of young musicians belting out tunes in Kiswahili, English, vernacular and Sheng. But in his palette, Sheng seems to outdo the rest of the languages. This creativity has been met with much economic success thus encouraging the youth to make a career out of music.

\footnotetext{
${ }^{9}$ A comprehensive study entitled " 45 years of Sheng: what has changed?" is underway by author.
} 
It is evident that the wave of musicians has been greatly influenced by African Americans like Ten cents, Tupak Shakur, Snoopy Dogg, Eminem, Shaggy, etc who have lately transformed music into a megabucks industry. The youth of the 1990s and 2000s stand in sharp contrast with those of the 1960s, 1970s and 1980 s that created precious little in the form of music.

\subsubsection{Fashion}

Creativity in the domain of fashion has not been very impressive. The youth in Kenya have not made many inroads into the area of fashion as they tend to turn to Western styles, especially African American. More importantly, the Kenyan nation has through various ingenious efforts attempted at creating a national dress. However, despite the availability of one in the early 2000s, its use is very limited to-date. This might be due to lack of national consciousness whose foundations are eroded by narrow ethnic loyalties. The post-Election violence in 2008 was symptomatic of the lack of national values (Iraki 2008).

Some young entrepreneurs have ventured into fashion design with great success. Using local and imported fabrics they design dresses for all occasions (weddings, funerals, engagements, official vestments, etc). Such entrepreneurs include Rialto fashions just to mention a few.

\subsection{Entreprise}

The creative genius has been seriously dampened by a school system that lays an inordinate focus on school subjects but leaves little if any time for innovation. The near-absence of entrepreneurial culture among the young and in Kenya at large explains in part the slow industrialization of the country.

Entrepreneurship has to do with devising new ways of doing things. It involves taking risks, moving away from comfort zones to explore new horizons.

The youth have been instrumental in creating small businesses, especially toy making, barber shops, kiosks, newspaper vending, etc. However, the reliance on employment rather than self-employment and the lack of seed capital has been a major deterrent in enhancing entrepreneurship among the youth.

The absence of an entrepreneurial culture among most of the parents provides the youth with no role models in the domain. Most African parents, unlike Asians and Indians, are clueless on how to start and maintain a business. This gap perpetuates a sense of dependence on the job market rather than a strong desire to engage the job market innovatively via self-employment or a mixture of both.

The availability of a Youth, Enterprise and Development Fund in Kenya has provided new albeit limited opportunities for the youth. The fund provides seed capital for small businesses upon presentation of a viable business plan. This is a step in the right direction. Further some banks are providing seed capital to support young entrepreneurs explore new market areas (Mungai $2008^{10}$ ).

\footnotetext{
10 "Youth and innovative enterprises". Paper presented at the seminar on Youth and cultural leadership in Kenya, Twaweza, 21-22 November 2008.
} 
It is noteworthy that the youth lack role models or mentors to steer them in the right direction. For instance, most parents are from the "old school" that produced labor for the job market. They went to school so that they could be employed later. Such parents are unlikely to inspire their children to engage in active investments. We review below how the youth can learn from experienced authors.

In the same vein, some African cultures are not in favor of entrepreneurship. They tend to promote excessive consumerism à l'americaine without due care about the future. In contrast with Asians, most African families do not engage in business. Such a situation perpetuates lack of capital in the family and contributes to impoverishment.

A youthful generation can begin to orient its mind, not on employment by an already saturated market, but toward job creation, small innovative businesses and an entrepreneurial approach to life.

\section{Pressures of urban life}

The youth in the City are confronted by myriad challenges that characterize urban life. Invariably, due to poor or absentee parenting, dearth of role models, etc the youth have to devise ways and means of navigating through these challenges. The challenges include:

- Lack of parental guidance

- Peer pressure to imitate each other

- Challenging national examinations

- Excessive teaching in schools to earn good grades

- Rote learning. No critical thinking skills

- Lack of innovation

- Lack of financial resources

- Drug abuse and addiction

- Intricate social relations, sex, etc.

- Inadequate sporting facilities

- Little if any civic participation

- Lack of counseling facilities

- Unemployment due to an inadaptive school curriculum, being choosy about jobs, etc.

- Idleness since they have no defined family or social roles

- HIV/AIDS

- Decay of moral values

- Etc

In order to survive in the jungle of the City, the individual youth will need courage, moral compass, determination and innovation, among other values. Further, success stories from experienced authors may shed some light on how the youth, and the society in general, can benefit from an attitude change toward life. We now review some insights from great authors who can serve as role models for the youth. 


\section{Gemstones to overcome challenges and excel in life 5.1 Rich Dad, Poor Dad}

Robert T. Kiyosaki adds the following line to the title above: what the rich teach their kids about money that the poor and middle class do not! The opus appeals to us to change our attitude toward life, and especially education. While it is important to get some good education, it is equally important to lead a successful financial life. In one scenario, the Rich Dad teaches the son how to make money, the poor Dad exhorts his off-spring to go to school and get a good "safe" job later. The simple consequence of these positions is that one of the kids (the business-minded) succeeds while the latter has mitigated success.

Kiyosaki provides some tips that could lead to sound financial success in the future. These include:

- Start minding your own business: keep your assets column strong and your liabilities column low

- Buy real assets not liabilities (things that lose value very quickly)

- Buy a house

- Buy stocks, bonds, mutual funds

- Have royalties from books, copyrights, etc.

- Make money work for you, but do not work for money

- The power of the spirit. The determination to succeed

- Have the power to choose without being influenced by others

- Choose your friends wisely

- The power of learning quickly

In fine, Kiyosaki provides insights on how we can break the vicious cycle of poverty by making the right personal, not collective, decisions. The idea of buying luxuries like cars and electronic equipment for starters sounds ill-advised compared to investing in a cooperative, stocks etc. The latter option means you can buy the luxuries from the gains made from the assets.

\subsection{Who moved my cheese?}

In Who moved my cheese? Dr. Spencer Johnson describes the anguish that follows after someone's comfort zone (Cheese) has been ruffled. The change could be a job loss, a transfer or any other calamity that looks impossible to overcome. Johnson presents what he calls an amazing way to deal with change in your work and in your life. Some of the ideas include:

- Having cheese makes you happy

- The more important your cheese is to you the more you want to hold on to it

- If you do not change you become extinct

- What would you do if you we' rent afraid?

- Smell the cheese often so you know when it's getting old

- Movement in a new direction helps you find new cheese

- When you stop being afraid you feel good!

- Imagining yourself enjoying the new cheese leads you to it 
- The quicker you let go of old cheese the sooner you find new cheese

- It is safer to search in the maze than to remain a cheeseless situation

- Old beliefs do not lead you to new cheese

- When you see that you can find and enjoy new cheese you change course.

- Noticing small changes early helps you adapt to the bigger changes that are to come

- Move with the cheese and enjoy it!

In brief, Johnson exhorts us to adapt to change in an innovative manner. We need to scour our environment for early signs of change in order to prepare ourselves better to deal with it. The youth who often times find themselves without cheese might be advised to act now instead of wondering what happened to their cheese.

\subsection{The Richest Man who ever lived}

Steven K. Scott's book The Richest Man who ever lived recounts the successful part of King Solomon. Like Clason, Steven explains that what made Solomon successful financially is still relevant today. Here are some of the tips:

- Wake up to reality

- Define your visions

- Effectively partner

- Pursue wisdom. Build your life upon it

- Be diligent. Persevere.

- Learn to listen

- Encourage others. Compassion

- Speak truthfully

- Pursue your dream

- Choose friends wisely. Avoid fools

- Live wisely

- Identify a mentor

Scott, without being too prescriptive, provides invaluable lessons that could steer the youth away from trouble and guarantee them an extremely fulfilling life.

\subsection{The Richest Man in Babylon}

George G. Clason in The richest man in Babylon provides a set of principles that can lead to a successful financial career. Detailing the life of a rich man named Arkad, Clason explains that the principles that made Arkad rich in Babylon are as true today as they were over 3,000 years ago. Here are the 7 principles or 7 cures to a lean purse:

1. Save money: for each ten coins, save one

2. Control your expenditures

3. Make your money grow

4. Avoid making losses 
5. Build a home

6. Insure a future income

7. Increase your ability to earn

Clason's analysis echoes Kiyosaki's advice on how to become rich. The youth could learn and practice the 7 steps to succeed.

\subsection{Women \& Money}

Suze Orman in Women \& Money provides insights to women that could be applied to both sexes to succeed financially. These include some 8 steps, namely:

- Harmony: agreement in feeling, approach and sympathy

- Balance: state of emotional and rational stability

- Courage: ability to face danger, difficulty, uncertainty or pain.

- Generosity: giving the right thing to the right person at the right time

- Happiness: state of well-being and contentment

- Wisdom: Knowledge and experience needed to make sensible decisions and judgments

- Cleanliness: state of purity, clarity and precision.

- Beauty: quality or aggregate of qualities in a person that gives pleasure to the senses or pleasurably exalts the mind or spirit.

Other points include:

- Make savings

- Make your money profitable: choose investments wisely

- Control your expenditure

- Invest for your retirement

- Hold title to your home

- Control your own destiny

Orman's approach to life and money in particular exhorts us to be careful about how we plan our existence. Her ideas are an echo of age-old wisdom as we shall see below.

\subsection{Don't drown in a tea-cup}

In his book, Ne vous noyez pas dans un verre d'eau (Do not drown in a glass of water), the psychologist Richard Carlson provides 100 pieces of advice on how to deal with life in general. Here are some of them:

- Do not drown in a glass of water. Avoid blowing things out of proportion.

- Watch out for the snow-ball effect. Small things can get very big and serious.

- Develop your compassion

- Do not forget the day of your death, your diary will still be full

- Let the others get the credit 
- Live each day to its fullest

- Be more patient

- Be the first to offer help

- Say "thank you"

- Smile to people

- Learn to listen

- Accept criticisms like compliments

- Be generous

- Be modest

- Mind your own business

The observations by Carlson appear commonsensical but they are often lacking in people. In the absence of moral beacons, these words can provide a reliable compass for life.

\subsection{Self-Reliance and other essays}

Ralph Waldo Emerson (1803-1883), essayist, poet and philosopher instructs on self-reliance, selfculture and individual expression. Some of his ideas include:

- Belief in your own internal resources, especially the power of your mind

- Act on your ideas as they might be novel enough to change the world

- Have a sense of history. Understand your context

- To believe your own thought, to believe that what is true for you I your private heart is true for all men - that is genius

- Put your heart in your work and do your best

- Nothing is at last sacred but the integrity of your mind

- Speak out and do not be afraid of being misunderstood. Pythagoras, Socrates, Jesus, Luther, Copernicus, Galileo and Newton were misunderstood! To be great is to be misunderstood.

- Be firm and do right

- A true man is at the centre of things

- Act singly. An institution is the lengthened shadow of an individual

- When a man lives with God, his voice shall be as sweet as the murmur of the brook and the rustle of the corn

- Insist on yourself, never imitate

- Rely on yourself, not property or governments

- Nothing can bring you peace but yourself

- Nothing can bring you peace but the triumph of principles.

- Cultivate your mind

In a country teaming with ethnic jingoism, the words of Emerson could help mould a new Kenyan who sees himself as the only agent of positive change in the world; a Kenyan who draws on his intellectual and social resources (friendship, love), and God to craft a new world of hope and success. Reliance on 
anything else (ethnic group, government, country) other than the person himself can only breed strife and discontent. Such a man will never find peace.

\section{Conclusions}

The Kenyan youth evolving in urban spaces are confronted by a host of challenges that include economic disempowerment, absentee parents, political manipulation, unimaginative school system, drugs, HIV/AIDS, etc. In the absence of role models, the youth have to devise innovative ways to navigate through life (sheng, music, fashion, etc). This creative streak could help them create a successful life amidst many hardships.

The entrepreneurial spirit could open new vistas and new ways of doing things. This spirit is lacking in Kenya due to cultural traditions that promote "education for employment" and thoughtless consumerism.

Self-reliance, self-drive, discipline, cultivation of the mind, etc are tools that can help the youth deal with the vagaries of urban life. Further, Kenyans can benefit immensely from words of the wise. The success of the individual could very well mean the success of a nation. As St. Exupery puts it in Petit prince:

\section{Let everyone cultivate their garden.}

\section{References}

Scott, K. S. (2006) The richest man who ever lived, USA: Doubleday.

Clason, G. S. (1988) The richest man in Babylon, USA: Signet

Emerson, W. E. (1993)Self-reliance and other essays, USA: Dover publications.

Johnson, S. (1998), who moved my cheese? London: Vermilion.

Carlson, R. (1997) Ne vous noyez pas dans un verre d'eau, Paris : Edtions Michel Lafon.

Kiyosaki, R.T. (1998) Rich Dad, Poor Dad, USA: Warner books.

Raponda-Walker \& Sillans, R. (2005) Rites et croyances des peuples du Gabon, Libreville : Editions Raponda-Walker

Haley, A. (1991), roots, USA : Vintage.

Iraki, F.K. (2004) "Cognitive efficiency: The Sheng phenomenon in Kenya" in Pragmatics, Vol 14:1, 55-68.

Abdulaziz, M.H. \& Osinde, K. (1997) "Sheng and English: Development of mixed codes among the urban youth in Kenya" in International Journal of Sociology of language 125: 45-63.

Ireri-Mbaabu (1996) language policy in Africa, Nairobi: General Printers. 
Wambugu, H. et al. (2006) The Agikuyu : their customs, traditions \& folklore, Nairobi: Wisdom Graphics Place. 